\title{
RONALD CAMPBELL GUNN'S VISIT TO PORT PHILLIP IN 1836
}

\author{
by Sophie C. Ducker
}

(with one text-figure, two plates and an appendix)

\begin{abstract}
In 1836 R.C. Gunn sailed in the Sloop Rebecca from Launceston to Port Phillip, Western Port Bay and Port Fairy. He was on the way to his new residence at Circular Head, Tasmania, but used the opportunity to look for grazing land on the mainland. He reports his observations during the cruise. The text is illustrated by newly available portraits of Gunn and his wife.
\end{abstract}

Key Words: R.C. Gunn, Port Phillip, Western Port Bay, Port Fairy, botanical exploration.

In BANKS, M.R. et al. (Eds), 1991 (31:iii): ASPECTS OF TASMANIAN BOTANY - A TRIBUTE TO WINIFRED CURTIS. Roy. Soc. Tasm. Hobart: 201-212. https://doi.org/10.26749/rstpp.124.2.201

\section{INTRODUCTION}

It was early in the 19th century that the lower reaches of Port Phillip Bay were botanically explored for the first time. With Matthew Flinders came three "botanical gentlemen" as the Admiralty called them: Robert Brown (Mabberley 1985), Ferdinand Bauer (Norst 1989) and Peter Good (Edwards 1981). Through the diaries of Robert Brown, Peter Good and Flinders (Flinders 1814) we have the first descriptions (1802) of the countryside near Port Phillip Heads. Ten months later, James Fleming, a convict but a knowledgeable gardener, assisted Grimes and Robbins to map the northern parts of the bay and to record trees and shrubs (Ducker \& Perry 1985). In October of the same year (1803), members of the aborted convict settlement at Sorrento listed common names of plants seen at the Sorrento site (Tuckey 1805) and in 1804 Robert Brown returned for his second short visit to the Sorrento settlement. From Brown's manuscript journal (Willis \& Skewes 1955), Willis (1955) extracted a botanical list of 96 species in 74 genera definitely known to have been collected by Brown in the Port Phillip area. However, no botanical publications dating specifically from the early part of the 19th century list plants from Port Phillip. The first published botanical account of the Port Phillip area (1842) is Observations on the Flora of Geelong, Port Phillip by Ronald Campbell Gunn.

Gunn was manager of the estates of William Effingham Lawrence, at Launceston and later, also that of Lady Jane Franklin. By 1848, he had established his position as a resident botanist, knowledgeable in diverse plant communities. He corresponded with and supplied plants from those communities to Sir William Jackson Hooker, Professor of Botany at Glasgow University, later at Kew. He was also associated with Hooker's son, Joseph Dalton Hooker, in his visit to Tasmania with the James Clark Ross expedition (1840-41), and the subsequent publication of the Flora Tasmaniae.
Correspondence with Gunn also influenced the Irish botanist, William Henry Harvey, to come to George Town in 1855 to collect seaweeds. The Mitchell Library in Sydney holds a rich collection of this correspondence with the Hookers and Harvey (see also Ducker 1988). Gunn's name is remembered in many Australian, particularly Tasmanian, flowering plants and algae (Buchanan 1988).

In his Observations, Gunn records 100 genera found in a parcel sent to him by two correspondents from Geelong. The 112 plants were collected in the neigh: bourhood of Geelong and the Bellarine Peninsula; Gunn names a few species which are common to both the Geelong region and Tasmania. The heading of the list reads: "Port Phillip Plants - received from Miss $\mathrm{H}$. Roadknight and Mr R. Burke. All marked thus and sent to Hooker 1842." Harriet Roadknight (1817-55) was born in England and married T.W. Vicary who, like Robert Bartlett Burke (1815-89) was a squatter. At the end of the paper, Gunn mentions his own earlier "short visit to the south coast of New Holland, in March, 1835". This reference to a visit to Port Phillip in 1835 has been a puzzle perpetuated in literature (Burns \& Skemp 1961, Maiden 1909, Willis, 1949, 1959, 1966), since no manuscript referring to the visit had been sighted.

The Mitchell Library, Sydney, holds a small note book (B122) containing a manuscript with the heading This is evidently the diary of Ronald Campbell Gunn who was Police Magistrate at Circular Head in February 1836, signed I. L. 8.5.34. The initials refer to Ida Leeson, sometime Mitchell Librarian. The manuscript is written partly in ink, partly in pencil; the writing varies and entries are obviously not written continuously. A transcript of the diary and the additional notes contained in the notebook follows; superior figures refer to explanatory notes which follow the discussion. Imperial measurements have been retained in the diary; one foot $=$ approx. $305 \mathrm{~mm}$; one yard $=0.9 \mathrm{~m}$; one fathom = approx. $1.8 \mathrm{~m}$; one mile $=$ approx $1.6 \mathrm{~km}$. 


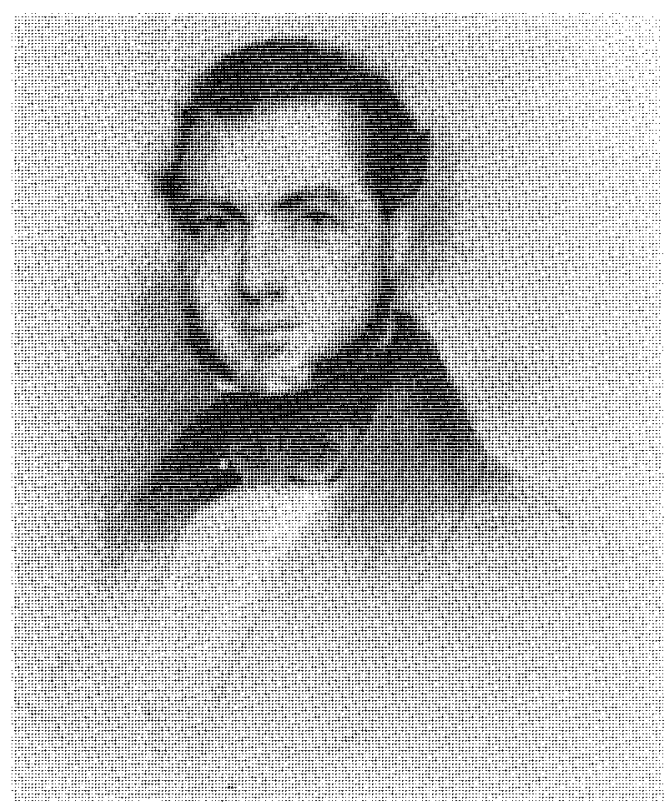

PLATE 1

Ronald Campbell Gunn. Attributed to Thomas Bock and dated c. 1848 by comparison with companion portrait (pl.2) which is signed and dated. Pastel drawing, $363 \times 310 \mathrm{~mm}$, inside contemporary Huon Pine frame $488 \times 440 \mathrm{~mm}$. Dixson Galleries, State Library of NSW. ZDG471.

\section{THE DIARY}

The sloop Rebecca sailed from Launceston on Friday $19^{\text {th }}$ Feb $^{y} 1836$ - about 3 P.M. and anchored at Rosevears Point that tide. -

Next morning about $1 / 2$ past 4 weighed anchor with a leading wind and reached a small inlet below Drumstick Island - where we were obliged again to anchor. - I have landed for an hour or two on Mr Reids ${ }^{1}$ farm but saw nothing remarkable -

At 3 P.M. the tide again turned but the wind was not favourable and we were obliged to beat all the way to George Town. - When opposite Mr Crisps farm - now the Lawrence's ${ }^{2}$ the wind blew very fresh - and neither Capt $^{\mathrm{n}}$ Tobin $^{3}$ or myself considered it advisable to lay to to land some flour etc and receive on board some Meat $\&$ Potatoes for sea stock, but as there was a probability of a continued unfavourable wind to send a boat from George Town with the flour $\&$ bring back the supplies. - Anchored at George Town about 7 P.M.
Spent the Evg. at Lieut. Friends ${ }^{4}$ who gave me a boat to go to Mr Laurence's farm with the articles before mentioned. - It is usual here to enumerate List of Passengers etc. etc. etc.

The Rebecca chartered for such time as might be required at $£ 40$ for 30 days is a Cutter of 29 tons, about 18 Months old built by Mr Plummer. - Mr Fraser the Owner sails in her. - A man named Shoten ${ }^{5}$ is Master - apparently a good sailor - and a crew of two Men making a total of four. Cabin Passengers Edw ${ }^{d}$ Tobin, formerly $\mathrm{Capt}^{\mathrm{n}}$ of West India Man in the Demerara Trade, and now on half pay as Master in the Navy apparently a pleasant companion. -

Charles Gray George ${ }^{6} \mathrm{Mr}^{\mathrm{s}}$ Lawrences oldest son one whom I had before rambled with and found a pleasant companion - good tempered - and evidently willingly influenced by the advice of one person older than himself - a Mr Anderson \& two men for Circular Head emerged from the hold in Spring Bay, but I saw little of them. -

Sunday Morning, $2 \mathrm{I}^{\text {st }} \mathrm{Feb}^{\mathrm{y}}$ at $5 \mathrm{O}^{\prime}$ Clock I was roused out of bed at Mr Watsons by Charles Gray informing me there was a fair wind. - I immediately posted to the wharf \& with old Tobin agreed to sacrifice our supply of Mutton \& potatoes rather than lose the fair wind - All Mr. Lawrences things were immediately carefully landed placed by me under Mr Wilson's care to go up in $\mathrm{Capt}^{\mathrm{n}}$ Friends boat in an hour or two - and I desired the Captain to weigh anchor I would follow in a whale boat - after I saw all put in store safe. - I obtained a bag of rice, a bag of flour, \& some coffee from $\mathrm{Capt}^{\mathrm{n}}$ Symers an old schoolfellow of mine being articles much wanted by Capt ${ }^{\mathrm{n}}$ Tobin for sea stock, as he was afraid our supply was rather limited — as the probable prices would be very low I agreed upon my own risk \& payment of half with Tobin. - I also borrowed a saucepan from Mr Wilson - then threw them into a boat, \& overtook my good ship before she had proceeded two hundred yards. -

The barque Isabella from England, Thistle for Portland Bay, Adelaide for Port Phillip, \& Sarah Ann for Port Fairy all sailed from George Town the same time. -

The wind veered round to the East and before we were outside of the Heads and we were obliged to make a tack out a long way beyond the Hebe Reef . - Before this time I had become seasick and was as miserable in bed as possible - anticipating every moment to see my yesterday's dinner - and did not again get out of bed until the vessel was entering the mouth of the River 
Mersey - The sea however during the day was very rough and the motion of the vessel very unpleasant We were tacking every now and then, and used every exertion to get as far to windward as possible - The entrance to Port Sorrell was rather difficult, so that the Mersey was attempted and fortunately we succeeded -

The Sarah Ann however that sailed at the same time was only able to get as far as Port Sorrell where she ran in. - About 6 A.M. 1 got on deck \& found Tobin heaving the lead on going over the bar of the Mersey and got as low as 6 feet. - but the average was two fathoms When we passed over which was half tide We had kept rather too elose to the East side. - We ascended the River as far as we could but the wind suddenly fell \& the ebb tide was so strong against us that we were obliged to anchor very close to the shore but in a safe place from any wind but a N.E. one. About 9 O'Clock a strong wind from N.E. came on when we again weighed anchor \& went up the River a quarter of a mile farther a point in smooth water where we again anchored for the night. -

The Mersey is an excellent harbour for small vessels, \& at spring tides the bar of the harbour has about 16 or 17 feet - The river of the tide is about 10 or 11 feet The width of the river inside the bar is about 200 yards, but narrows considerably a little way up until it is little more than 70 to $100 \mathrm{yd}^{\mathrm{s}}$. - The water is salt \& the tides rise for 7 Miles from the Mouth, and about 3 Miles up forms a large basin. - The greatest depth of water is on the west side until the stuble a low sand spit on the East side about half a mile from the entrance, where the deepest water is on the East side of the River with fine sandy bottom. - The trees appear very large \& the forest dense the west side $\&$ almost equally so on the east side, but I had no opportunity of landing to examine the character of the Country. - There are no hidden dangers at the Mouth of the Mersey and should the Climate \& soil enable proprietors on the banks of the River to raise crops of anything, the harbour will be found most valuable for small craft. - - I enjoyed a hearty supper \& sound sleep. -

Monday $22^{\text {nd }}$ Feb $^{y}$. at 5 O'Clock A.M. Capt $^{\mathrm{n}}$. Tobin got up found a fine, southerly wind, \& roused up the Captain \& all hands to get under weigh --- which did not occupy many minutes the wind veered round to the Eastward so that we were enabled to sail along over a smooth sea with the wind nearly right aft. - We passed within a mile or two of the prominent headlands, and had a very fine view of the Country - which appeared to be densely wooded - A Number of Rivers empty themselves between the Mersey and Circular Head, but

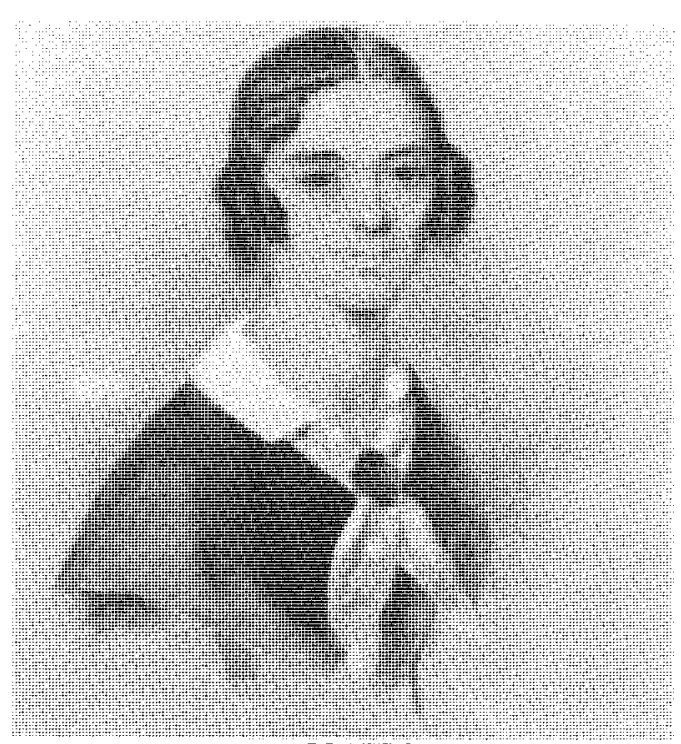

PLATE 2

Margaret Legrand Gunn (née Iamieson), whom Gunn married in December 1839 as his second wife, the Rev. JohnLillie officiating. Portrait signed and dated (1843) lower left "T. Bock". Pastel drawing $383 \times 316 \mathrm{~mm}$, inside contemporary Huon Pine frame $484 \times 440 \mathrm{~mm}$.

from all accounts of visitors to them, they hold out no inducements to settlers.

We passed Rocky Cape about $1 / 4$ to 3P.M. and at $1 / 2$ past 5 were at Circular Head _- An excellent run for our small vessel I need not add that as usual I was in bed nearly all day - The view of Circular Head is peculiar, but does not present that appearance I was led to expect from the view in Dr. Ross'es ${ }^{7}$ Almanak The view of Circular Head in Mr. Bischoffs work ${ }^{8}$ is also extremely incorrect - a rock in the foreground not existing. - There is a small wharf on the SE side of the bluff, on Circular Head - where we brought up and were moored in a few minutes, head and stern. Immediately dressed and waited upon Mr. Reeves ${ }^{9}$ the Agriculturist - finding both $\mathrm{Mr}$. $\mathrm{Curr}^{10}$ \& Dr. Hutchinson ${ }^{11}$ absent - I also called upon Mrs Curr. The agricultural Establishment \& Mr Curr's House are about a mile from the landing Place and on another part of the Peninsula - Highfield House is a beautiful Mansion \& the grounds apparently well laid out, but not extensive. - 1 spent the evening \& slept at $\mathrm{Mr}$. Reeve as I had a great number of questions to ask relative to supplies of food, Prices etc etc I regret to add that 1 found Mr Curr \& Dr Hutchinson had quarreled and that matters were likely to be very unpleasant No very pleasant prospect for me. - 
Tuesday $23^{\mathrm{d}} \mathrm{Feb}^{\mathrm{y}}$ - The wind had increased during the night to a gale from the North East sending it a fortunate circumstance we were in a safe anchorage as we should have been unable in our small vessel to have got through the sea. - I got a cart from $\mathrm{Mr}$ Reeves, $\&$ before 10 A.M. had all my traps removed into my future residence. - It is pleasantly situated, but in bad repair - the place however al together looks bleak andmiserable - I however anticipate much time for my Natural History pursuits. -

Capt $^{\mathrm{n}}$ Tobin, Charles \& myself had a splendid dinner at Mr. Reeves (who has a wife and 11 children $\longrightarrow$ ) and returned on board about 10 O'clock. - During the day I rambled over a large portion of the Peninsula and as far as the isthmus that connects it with the mainland -

Mr. Anderson our fellow passenger had resided here for some years is a young man of excellent education and information, and has been of very considerable service to us in giving information upon various points useful. - Mr. Fraser got a whaleboat ready .

Wednesday $24 \mathrm{Feb}^{\mathrm{y}}$ 1836. The Gale continued from N.E. so as to render impossible to get out of the Bay or if at sea would have obliged to run into a Harbour a drifting rain came on about $1 / 2$ p. 10 O'Clock which led to the hope of a change of wind - towards afternoon the rain \& wind increased making our little Cabin not very comfortable — We all dined with the Storekeeper \& spent the Evg. with him - he having taken pity on us . - He has a store $\&$ residence near the wharf. -

I omitted to mention that on the $23^{d}$ I removed all my baggage in a Cart to my future residence - it is a house pleasantly situated — \& pretty commodious. -

25th Feby. Thursdy. - The Wind lulled last night about 12 O'Clock and this moming the sea was considerably down - with the Wind N. to N.E. we got our whaleboat on board all hands assisting - and got fairly under weigh about

1/2 p. 7 A.M. The Wind was almost dead against but I thought it preferable to do something - We beat up to windward as far as possible and as the Wind continued against us - the Captain bore up under the South side of Robbin Island about 3 P.M. \& anchored - this was contrary to Mr. Tobins opinion as he conceived we could easily have reached three Hummock island in the Evg. \& anchored -

I had been ill all day \& requested the boat to be put in the water that I might land - to look about - We all took our Guns \& walked across the S.E.point to the sea about 2 Miles. - The soil appears very good in places covered with dense Teatree (Melaleuca N.7) and I believe abundance of fresh water, as is usually the case in the tea tree lagoons \& scrubs. - This island belongs to the V.D.L. $\mathrm{C}^{\mathrm{y} 12}$,

I found among the Plants Correa Backhousiana very abundant down to the beach - also a Banksia probably the Australis of very dwarf habit seldom exceeding 3 feet to 4 . - A large saltwater lagoon forming a good boat harbour was covered with two species of Salicomia.One of a shrubby habit similar to one on Middle Island harbour. The Birds seen were hawks, Quail, \& a great number of the ground Parrot (P. terrestris) also two species of parakeet, \& the common green Parrot. - On the beach lay the bones of a finback whale ${ }^{13}$ said by our Master to have measured upwards of 90 feet in length - its Skeleton was not perfect, but from what we saw it must have been very long — The island did not meet my expectations, but I am told the Northern end is the best. - No Land that I saw would feed many sheep. - We went on board about 6 P.M. it was then high water. -

26th Feb ${ }^{\mathrm{r}}$. Friday - Weighed Anchor about ${ }^{1} / 4$ to $7 \mathrm{~A} . \mathrm{M}$. having waited for the tide - so the Capt ${ }^{\mathrm{n}}$. said, - I was on deck at $5 \&$ roused him up, but the devil himself could not get him to be active - He is a very lazy man - \& excessively nervous - treating our little vessel of 27 tons with as much care near land as if she was a 74

It was drizzling drain [sic] all night with the wind still from the N. to N.W. We however tacked up towards 3 Hummock Island, \& in the Evg the wind coming from a point or two further west enabled us to take our departure for King's Island which we expected to reach next day about noon - The wind freshened during the night, \& squally with rain continued - Sick \& in bed as usual. -

27 th $\mathrm{Feb}^{\mathrm{y}} \mathrm{Sat}^{\mathrm{y}}$ looked in vain for Kings Island \& at last saw land about 3 P.M. on our larboard bow - One knew it to be Kings Island \& that we were in Seal Bay - Another thought we had sailed better, but after sailing half an hour more, the Sky which had been hazy all day cleared a little displaying a series of high cliffs, convinced $\mathrm{M}^{\mathrm{r}}$. Tobin we had over run our distance about 40 Miles - \& that we were to the East of Cape Otwav!! No small consternation was felt. - The wind was blowing strong from the S. West, but as we were quite lost - we could not safely venture any further on our course towards Portland Bay until we ascertained where we were. - 
Cape Otway bore from us W.S.W distant 16 Miles \& the Gale from the S.W. continued, - we bore off and hove to for the night . - the Gale increased \& washed our decks decks [sic] pretty clean - it also rained all day - A severer gale I seldom remember, \& I really had some small fear for our Craft - I was dreadfully ill \& had not been out of bed since I left Robin ${ }^{14}$ Island - We lay to during the night under a balance reefed mainsail, \& close-reefed foresail. -

$28^{\text {th }}$ Feb $^{y} 1836$ Sunday The wind continued strong from the S. West with rain - Weather very dirty - we made sail for the land, but found we had drifted much further to the Eastward than expected -- \& that we were N. E. of Cape Patton - It was too late \& the weather too bad to allow our going into Port Phillip or Westem Port. - We therefore stood off \& on all night towards 10 P.M. the weather became more moderate, \& the wind veered round to W.S.W. The Country appeared beautiful $-\&$ very lightly wooded as far as we could see - two entrances very similar to those of fine rivers were passed about [blank] miles on the Port Phillip side of Cape Patton.

I longed much to explore them - I have little doubt they are rivers from the appearance of the openings. -

29th Febr. Mondy At daylight we ran in for Port Phillip which was close to us, the Country on our larboard side was very beautiful surrounding a large Bay which evidently affords good shelter from S.-S.W. \& W. winds - No trees of any size appeared close to the beach or many larger ones inland - the country looked very green $-\&$ beautiful. The entrance to Port Phillip is rather intricate but Tobin took the Command \& I must say did matters nicely. - As we advanced farther the Western country appeared covered with wood, but no opinion of the character of the Country could be formed from on board ship - Mr Tobin was anxious to run up to the Settlement ${ }^{15}$ but as I had no business there \& it was 30 miles off $-\&$ evidently contrary to his inclination induced him to bear up for Arthurs' Seat ${ }^{16}$, distant about 13 Miles where wood \& water could be got - Our visit to Port Phillip is entirely contrary to my repeatedly expressed wish, \& indeed order, but the winds were made an excuse for our visit. -

After entering between the Heads we sailed direct for Arthurs Seat being nearly due East of the Entrance The Country a few miles in from $\mathrm{P}^{\mathrm{t}}$ Nepean along the Bay looked very beautiful, the grass very green, $\&$ in some places studded with She Oaks \& Honeysuckles like a Gentlemans Lawn. We kept the lead going on running up to our anchorage $\&$ we commenced in time as had we delayed many minutes longer we should have been ashore on the flats which in that part of Port Phillip are very extensive \& run some miles off shore - The Colour of the Water is good general guide for a small vessel. -

We anchored about 10 A.m. off a place near where we presumed water to be marked by Flinders ${ }^{17}$ in 4 fathoms fine sand Arthurs Seat bearing ENE three or four miles. - About 11 OClock after getting our Guns in order, we landed in the Whale Boat at a place where it looked like a water course, but found we made a mistake - Charles, my servant \& self remained on shore to find water - Tobin \& the boat returned on board to move the vessel a little nearer Arthur's Seat should we find water. -

I felt myself very weak \& ill not having eaten or drank anything for upwards of three days - I attempted rice water twice but found the pains of vomiting so great as to induce me to starve in preference. -

I kept in from the beach in hoping of finding a run of water \& walked parallel with the shore - - the soil was light sand or sandy loam, but covered in most parts up to my waist in the most beautiful Kangaroo grass I ever saw -. I never saw it so abundant \& rich in my life \& I was astonished that such poor soil could bear so fine a crop - The trees were a species of Banksia about the size of our V.D.L. one but the leaves larger longer, \& not serrated - species of Eucalyptus of no very large size, but luxuriant, a few green wattles, Cherry trees, (Exocarpos Cupressiformis) \& one or two others such a Fabricia, Bursaria, etc.

The undershrubs were not numerous the Daviesia latifolia being the principal. - The Trees did not appear bent over in any direction \& being of a fine size \& luxuriant to within 3 yards of the beach leads me think there is no prevailing wind likely to be troublesome, at least off the Bay.

I walked along for nearly a mile keeping on \& out from the beach with land equally poor $\&$ the grass in general equally rich in some low places it became coarser but in general good feeding ground \& did not appear to have been burned for a few years. - In walking along the beach I saw a light bunch of rushes close to the sand $\&$ about 5 yards off - I went to them \& found a deep pond of fresh water - it extended up for some yards \& contained abundance of water - had not rushes which I knew usually grow in or near water, attracted my attention, a person walking along the sand would not have seen it. - The bed of a small creek meandered inland for a considerable distance from the pond at the beach filled with Calystegia sepium, \& Lythrum salicaria 
in full flower - they are both marsh plants, \& usually grow in or very near water, \& although the bed of the creek was dry I have little doubt water was one or two feet below the surface - The pond filled with high rushes near the beach is in my opinion a spring, \& the water good.-

An immense number of native huts \& bivouacs were about in all directions, \& fires in abundance with mussles, Cockles \& oyster shells in heaps. - a track of natives to the pond was also plain together with the track of a dog \& one or two natives along the beach The dog track not many hours made but the native track two or three days. - I made a fire on the beach by setting fire to a brush wigwam, as signal of having found water, when I had the satisfaction of seeing our frigate anchor abreast of us $\&$ Tobin shortly after landed. We dined upon Aberdeen fresh salmon ${ }^{18}$, biscuit and wine - indulging also temporarily in water - I enjoyed it much having my unfortunate gun-room empty. After dinner we all walked northward towards Arthur's Seat \& saw a continuation of good feeding land but no water -

Charles \& I walked direct inland from the Watering Place \& found the land to improve in quality but evidently under water in winter forming long lagoons. The size of each not more than 10 to 20 acres - the intermediate spaces covered with fine Kangaroo grass - I was afraid to ramble much further inland by ourselves as there was good cover for the aborigines The flats were covered with a species of Senecio in flower \& in my opinion indication of good soil. - - If the country continued of the same character further back I think few places possess greater inducements to settle, - always excepting the Natives \& dogs. Pigeons were exceedingly numerous -- as also various species of Parrot \& Paraquett, Quail not very abundant but sufficiently so.

fishing for Rays.

\section{Westernport $2^{\text {nd }}$ March 1836}

Flagstaff ${ }^{19}$ - Swamp - shallow at low water--Sharks - Swans

Plants - Acacia, Aster \& Ozothamnus, Cassytha Salicornia - [indecipherable] \& peculiar

Pomaderris - plain of good soil but miserable vegetation - Xanthorrhae

Up 8 or 9 until $5 \mathrm{pm}$. $3^{\text {rd }}$ March - landed 11 am as the vessel attempted to beat to the Eastem passage between Port Phillip \& Main Water - two places — Mutton birds - Sand Hills - Soil at old Huts -.. Tobin surveying channels. — Typha — Grass poor on Sand Hills. - - dog marks -

$4^{\text {th }}$ Mar 10 Am. landed at Mr Griffith Barker's ${ }^{20}$ Est $^{\text {te }}$ - Natives — dogs - Soil \& Grass good flats - Bass River - dined - fresh water 5 to 8 miles up the windings of River - $1 \frac{1}{2}$ miles in a direct line Splendid Country both sides - Bell Bird - banks $20 \mathrm{ft}^{\mathrm{t}}$ high - river 55 lines wide or as wide as boat \& 2 oars - $\mathrm{ab}^{\mathrm{t}} 4$ miles from good land to Kennedy's Cove. - good land also at Point between Basses River $\&$ Kennedys Cove - Sheep of Swanston ${ }^{21}$ Salicornia - tea tree - ducks \& swans - channel of River -

Bivouac - [sic] Small island at 9am - fire - supper etc etc very small

5 Mar Sat ... up at $1 / 2$ p 6 landed at Yellow Point dead sheep - good land visited old Settlement ${ }^{22}$, Houses, flagstaff etc. boat met us at Water-Brick Hole -good water - describe locality - opinion plenty of water - land told is good to River \& very fine higher up - dined on French Island as afraid to stick on flats -

Pelicans, Swans, ducks, etc. French Island much burnt - Margarets Island \& pulled up vessel - arrived there at $1 / 2$ p 5 PM vessel been on back getting her bottom looked at $\&$ pitched as she made a great deal of water -

Fresh water in two holes on point at careenage - lots of sharks - size - enormous. - Blacks troublesome Swells not numerous.

6 Mar. Sund ${ }^{y}$ Started 10 am to visit Churchhill Island ${ }^{23}$ — very woody with tea tree lots of Rays — killed 47 - ret $t^{d}$ on board \& got under weigh c. 1/4 p 2 PM becalmed at the mouth of the Port where there was an extraordinary ripple - between the tides - wind $a b^{t}$ N.E in the Ev ${ }^{g}$ until we got near Cape Otway -

7 Mar Mond - becalmed early in the morning \& continued most of the day. $A b^{t} 12$ the wind came round to the south west in our teeth \& we ran in for the shore $\&$ anchored in a small roadstead near Cape Patton sheltered from SWest \& South winds $-a b^{t} 3$ P.M. landed - with our Guns found a nice stream of water of good size named it Tobin River - Ducks abundant \& tame - Musk tree, Blue Gum, Tares - Ferns, Fern tree--peculiar Grass running $12 \mathrm{ft}$ up shrubs of various 
kinds - other plants - vegetation put me much in mind of V.D.L. - Shot 2 Sand Pipers red orbits -.- red legs — \& Base of Bill red - tips black - went on board at 6 P.M. found a number of star fish \& some good chitons on rocks.

8 March Tues ${ }^{y}$ Got under weigh - About $1 / 2$ p6 AM Wind $a b^{t}$ W.S.W. - fell calm inmediately after - \& in the afternoon we were not 5 miles from where we anchored - about 3 PM a breeze sprung up from about E. S. E. \& we jogged on our course - passed Cape Otway bore N. 5 or 6 miles Old Shoten our Skipper steered west until $1 \mathrm{AM}$ of the $9^{\text {th }}$ to avoid some imaginary recf some person had told him of - Breeze good - going about 5 miles an hour. - Sea rough there being a heavy S. West swell. -

9 March Wed ${ }^{y}$ About 4 AM altered the vessels course to N.W. to come nearer the land - about $6 \mathrm{AM}$ it was $a b^{\ddagger} 3$ to 4 miles distant. - saw some islands \& peculiar hills like the Mouth of a River - of which Tobin took a sketch - bore in as close as we could but dare not venture too near - a heavy sea running - the Coast was precipitous but not high - apparently sand stone - land behind must have been low as we could not see any portion of it -

Anchored at Port Fairy at 1 PM having run ab 80 miles in 16 hours

Port Fairy is a good roadstead from all winds but East \& S.E. it is found of the N.E. island called Lady Julia Percys - 5 islands in all - fresh water River continued further on.

9th Mar continued - Whalers 8 men - huts - flagstaff - island good - potatoes - purple flow Lotus, Correa, Lavatera, Kangaroo, Grass - Shells - - myself very weak indeed more so than I have been for years Had sone soup $a b^{t}$ 5PM \& felt better, bivouaked [sic] in an unfinished $\mathrm{Hut}^{24}$ good fire - slept sound native fires numerous not troublesome - heavy sea in Bay, Hatches battened down. Copy Sketch of Harbour - beautiful Turnips - Spring of water. -

10 Mar. Thursday —- rose at our Bivouac $a b^{t} 7$ - wind still strong from East - prepared to go inland exploring. -Steered $a b^{t}$ North \& went $a b^{t} 4$ miles - Grass good [indecipherable] Kangaroos - Soil sandy with sandstones abundant - Water - lagoons - inlet \& natives - Swans \& Pelicans - Nat ${ }^{\mathrm{s}}$ Huts Character Birds -- Portland Bay 25 to 30 miles - better than Port Fairy - $\mathrm{ret}^{\mathrm{d}} \mathrm{ab}^{1} 3 \mathrm{Pm}$ to Station - Tobin very tired -_ Country very low - Wind still at N. 16 miles - being the only ground visible - Percy Isles - slept as before - intended going to Portland Bay next morning.

11 Mar. Fridy Went on board early \& got under weigh, but the wind coming from the North rendered it so favourable to explore Coast \& then Eastward that I forsook visiting Portland Bay - unless wind changed - Sand Hills for 14 miles from P. Fairy - then Sandstone cliffs - strata horizontal -5 small islands - apparent mouth of River - but break right across mouth. - sailed from 1 mile to $1 \frac{1}{2}$ miles from shore - beautiful day \& one two or three small openings but none promising to be a river - \& most with sand right across.

12 Mar. Sat. In the Course of the night we sailed along $a b^{t} 20$ Miles of Coast that we had closely examined on the trip down - \& commenced on this moming a few miles W of where we began going westward - Cap ${ }^{t}$ Tobin at the Mast Head with a spy Glass - A large opening $a b^{t} 40$ miles from Port Fairy seen with an expanse of water inside - but we stood close in \& found a bar \& reef to extend completely across sailed along very close \& spared no pains - Sunset within $a b^{t} 6$ miles of Cape Otway - from which we took our departure for Launceston so far foiled in our attempts - wind was from the N.E. \& had continued $a b^{t}$ that for the last 2 days. -

13 Mar. Sund ${ }^{y}$ Steered from SSE to SE by S. - being as close as She would lie to the wind which occasionally veered a point or two _- made Kings Island _- It \& Cape Otway in sight all day - Calm all night wanted to go to new grass - Tobin \& Port Phillip -

14 Mar Mond ${ }^{y}$ - wind continued from the East \& we made very little progress.tacking backwards $\&$ forwards much tossed $a b^{t} \&$ very ill. -

15th Mar. Tues ${ }^{y}$ King Istand in sight astem [sic]. - Wind still E - sighted the Hunters blew very fresh \& Shotten wanted to run in - $a b^{t} 9$ to $10 \mathrm{Am}$. saw Circular Head - \& the Wind coming northerly were unable to weather it - Weather very dirty squalls \& rain \& heavy sea If we had carried on to Geo Town we should have been obliged to heave to all night - prefered going into Circular Head where I anchored $a b^{t} 1 / 2$ p 12. - Invit ${ }^{d}$ by $\mathrm{M}^{\mathrm{r}} \mathrm{Curr}$ - \& Horses sent down. - Tobin on board. - Rode out with Mr Curr round fields. - dined 6 PM - excellent - felt ill — \& went to bed 120clock differences great between Curr \& Hutchinson -

16 Mar. - Wed, visited my future residence with Mr Curr - differences with Gov ${ }^{t}$ - many - seen Dr. Hutchinson etc. etc. etc. Shotten \& one of sailors 

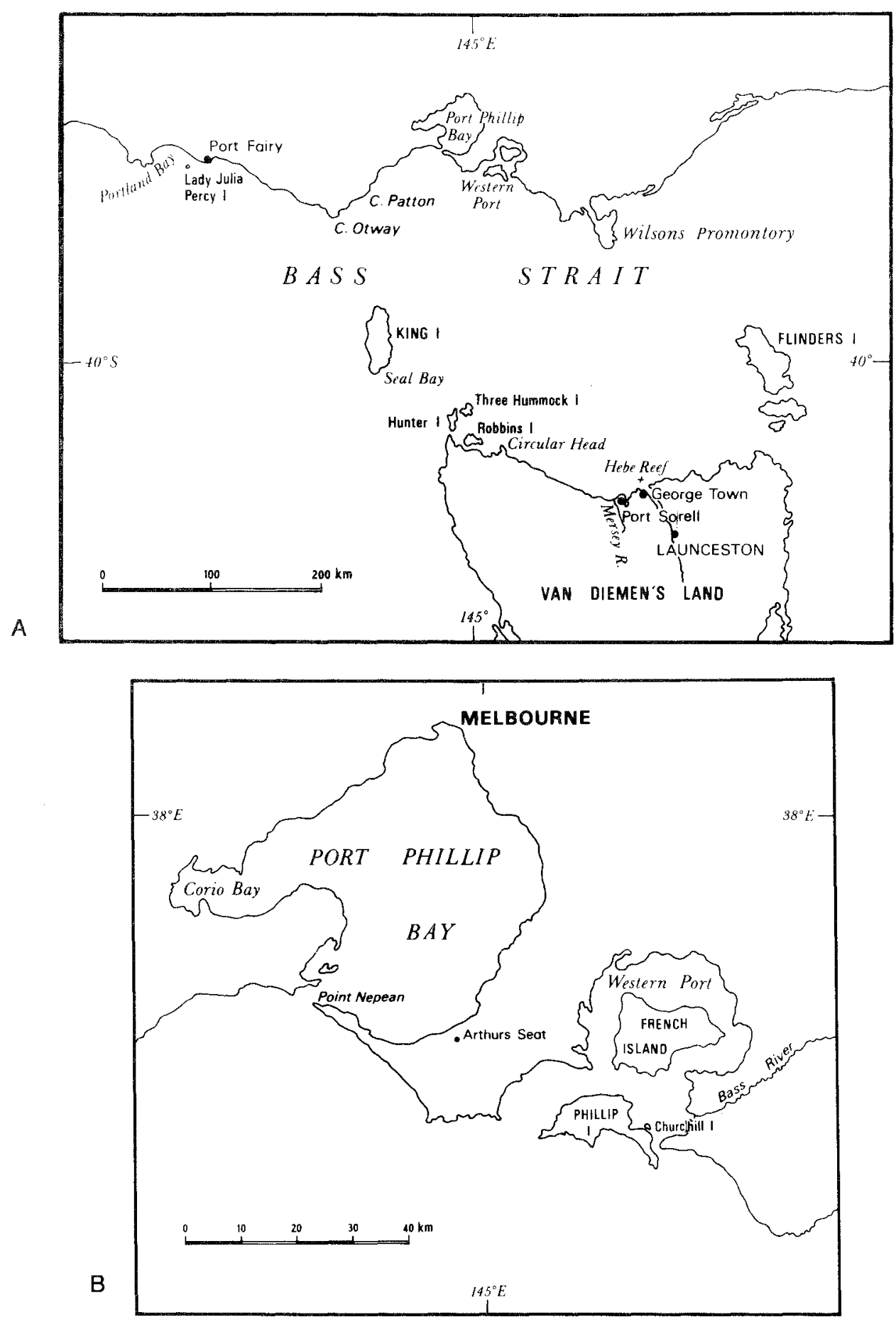

FIG. I - (A) Bass Strait; and (B) Port Phillip Bay and Western Port area. 
broached my wine \& drunk yesterday \& today, could not get under weigh this Evening - - so that obliged to postpone until tomorrow

17 Mar. Thursd ${ }^{y}$ rec $^{d}$ some wool on board from VDL Cy.

\section{ADDITIONAL NOTES IN THE INTER VENING PAGES OF THE DIARY}

Left Circular Head 25/2/36 at $1 / 2$ p 7 Wind $N$ to NW. -Anchored at Robbin Island 3 P.M. -

Left Robbin Island $26 / 2 / 36$ at $1 / 4$ to 7 Wind N to NW.

Anchored at Port Phillip at 10 Am 29/2/36 Monday Arthurs Seat bearing E.N.E. from 3 to 4 Miles in 4 fathoms, fine sand. - landed at 11 Oclock -

\section{Mar. 1836}

Weighed Anchor from Port Phillip at 6 Am. Wind N.N.E. passed the Head at 9 AM fell calm - about 10. $a b^{t} 12$ the wind veered round to S.E. \& looked very dirty about $3 \mathrm{Pm}$ we were obliged to alter our course \& go to Westem Port where we anchored $\mathrm{ab}^{\mathrm{t}} 1 \mathrm{AM}$.

large white Gull - shot at Circular Head 24 Feb $^{y}$.

Iris white -- legs yellow, - Bill yellow (orange) with deep-red shade at tip - Orbits orange \& carumulated [?] slightly .

Small white Gull — Cir Head 24/2/36

Iris white - Orbit red -

Bill coral red - legs — red

Shag — shot at Robbin Island 25/2/36

Iris - whitish brown, with a circle of sea green between it \& pupil — Orbits — brown - Bill blackish brown - legs black -

Parrot blue \& yellow Iris scarlet -

Small Bird Iris brown

\section{DISCUSSION}

The document transcribed here is clearly the diary of Ronald Campbell Gunn. At the time of the journey described, he was living at Launceston, whence the
Rebecca sailed, and it is apparent that he was well acquainted with landholders on the banks of the Tamar while sailing up to George Town. Furthermore, in the abridged letters of Gunn to W.J. Hooker, published by Burns \& Skemp (1961), Gunn writes of his planned move to Circular Head on 5 February 1836 and of his new address there, while on 5 September 1836, in a letter, he speaks of his initial collecting at Circular Head. In this diary, Gunn, in describing the cruise of the Rebecca, records his first visit to his future residence and leaving his belongings there.

There have been some conjectures in the literature as to the year of Gunn's visit to Port Phillip Bay; from the diary it is apparent that it is written in 1836 . I believe the difficulty arose through Gunn's 1842 paper, where he himself mistakenly quotes the year 1835 for his earlier visit.

From the document it is apparent that Gunn was principally interested in good grazing land. Balaam (1965) states that Gunn himself chartered the Rebecca with a view to squatting on the mainland. Gunn, indeed, commented on the grazing potential of every newly discovered tract of land but there is only indirect evidence that he himself had chartered the vessel, in that he referred to "my good ship" and bought the provisions. There were other passengers on board and it may have been a joint venture. There is, however, no doubt that Gunn was very knowledgeable about plants, animals and soils. He had only recently, with Backhouse, compiled the first extensive list of Van Diemens Land plants (Backhouse \& Gunn 1835). His descriptions of the park-like landscape of the heads of Port Phillip and of the cliffs of Port Fairy, and his appreciation of their beauty are most interesting.

The other point of interest in the manuscript is the fact that the visitors from Tasmania had so much information about the Port Phillip and Western Port districts. The new settlement at Port Phillip, Melboume, was only in its infancy, not quite a year old. Gunn was well informed and had seen maps, and must have carried copies of all the relevant and available maps of these areas. The dissemination of knowledge was rapid and efficient.

This paper presents the entire document from the notebook, even the fragments found in the middle section of the diary. The people are identified as far as possible in the notes; plants and animals are listed in the appendix.

\section{NOTES}

(l) Reed, Henry (1806-80), landowner and shipowner, lived at that time at Launceston (Australian Dictionary of Biography $(A D B) 2$ ).

(2) (a) Lawrence, William Effingham (1781-1841), 
landowner, lived at Formosa near Launceston. $(A D B 2)$. (b) Lawrence, Robert William (180733), eldest natural son of William E., botanist, arrived in Tasmania in 1825; is said to have been friendly with W.J. Hooker, whom he introduced to Gunn, who then became interested in Botany. R.W. Lawrence married Ann Wedge, niece of the surveyor John Helder Wedge (personal information by Jean Uhl).

(3) Tobin, Captain, called Edward by Gunn. According to the Navy List (Gt Britain) Edward Tobin received Seniority as a Lieutenant I1 July 1800, Master of the Royal Navy 24 December 1824; he is listed as a Master until 1851 and for the years $1852-57$ as a halfpay Master.

(4) Friend, Matthew Curling (1792-1871), port officer at Launceston, later at George Town; he installed a line of semaphore from George Town to Launceston; Anglican and active in building the church and rectory at George Town.

(5) Shotten (Syme 1984).

(6) Charles Gray George, oldest son of Mrs W.E. Law rence from her first marriage; she was widowed when she married Lawrence in 1826.

(7) Dr Ross's Almanack (1832) shows a picture of Circular Head; in the distance on the hill is Highfield the residence of Edward Curr and on the right of the Head is Beach Cottage where Dr Hutchinson resided.

(8) Bischoff (1832) also contains a picture of Circular Head.

(9) Reeve, the Agriculturist. I have been unable to find any more information about him.

(10) Edward Curr (1789-1850), the first representative and manager of the Van Diemens Land Company. On arriving from England, he lived with his family in a small cottage called Highfield Cottage at Circular Head until, in 1835, the mansion Highfield House was built.

(11) Dr J.H. Hutchinson was sent out from England by the Van Diemens Land Company in response to Curr's urgent appeal to the directors for a medical man and one better able to keep the company's books. He was a good doctor and bookkeeper and acted as secretary when Curr was ill. In 1836 he left to take up private practice in Hobart. He was followed by DrMilligan from England, with whom Gunn had much association.

(12) Gunn is mistaken; according to the map of Meston (1952), Three Hummock Island did not form part of the Van Diemens Land Company.

(13) Most likely Gunn is referring to the Fin Whale Balaenoptera physalus L., which has a similar appearance of the skeleton to that of the Blue
Whale Balaenoptera musculus L.; the latter reaches the larger size described by Gunn and occurs plentifully in Bass Strait (information supplied by Mark Norman).

(14) Robbins Island.

(15) Embryonic Melbourne.

(16) Arthur's Seat named by Lieut J. Murray in 1802.

(17) Flinders' map of 1814 shows fresh water on the foreshore near Arthur's seat.

(18) Aberdeen fresh salmon refers most likely to the Australian Salmon Arripis trutta Bloch \& Schneider which has a similar pink flesh.

(19) In November 1826, Captain F.A. Wetherall erected a flagstaff near the intended settlement, later known as Corinella (Hist. Rec. Aust., Ser.III, Vol. 5).

(20) Griffith Barker; so far unable to trace.

(21) Captain Charles Swanston in the barque Norval, with 1000 sheep on board, took shelter in Western Port Bay in January 1836. Most of the sheep were lost (Hist. Rec. Aust., Ser.III, Vol. 5).

(22) Settlement at Corinella was set up jointly by Captain Samuel Wright of the third regiment, when he arrived in the brig Dragon, and by Captain F.A.Wetherall in H.M. Sloop Fly (Rosenman 1987).

(23) Churchhill Island, discovered in 1801, was named and cleared for the first Victorian garden by the naval officer James Grant (1772-1833) on the Lady Nelson.

(24) In 1836 the whaling industry in Portland Bay was well established, especially Port Fairy. This was the first settlement of the Port Phillip District, set up mainly by Edward Henty and William Dutton. By then both had built houses and the settlers were supplied with vegetables and other garden produce from the locality (Powling 1980).

\section{ACKNOWLEDGEMENTS}

I gratefully acknowledge the help of Dr T.M. Perry in providing much background information and for compiling the maps which were drawn by Chandra Sagasuriya. Dr P. Short identified as far as possible the plant names used by Gunn in the diary. The Librarians, Paul Brunton of the Mitchell Library, and Jock Murphy of the Baillieu Library, were most helpful. Useful discussions were had with Miss Helen I. Aston, Mrs Jean Uhl, Mr Mark Norman and Mr N.J.B. Plomley. I owe thanks for answering queries to both Paul de Serville and Alex Buchanan. 


\section{REFERENCES}

Australlan Dictionary of BIOGRaphy, Vol.2, 1967. Melboume University Press, Melboume.

BACKHouse, J. \& GunN, R. C., 1835. Index plantarum ... of Van Diemen's Land. In Ross, J. (Ed): ROSS'S HOBART TOWN ALMANACK AND VAN DIEMEN'S LAND ANNUAL. Hobart Town: 61-114.

BalaAm, V. E, 1965: Ronald Campbell Gunn. Vict. Nat. 82: 90-91.

BIschoff, J., 1832: SKETCH OF THE HISTORY OF VAN DIEMEN'S LAND. John Richardson, London.

Blakers, M., Davies, S. J. J. F. \& ReWIY, P. N., 1985: THE ATLAS OF AUSTRALIAN BIRDS. Melboume University Press, Melboume.

Buchanan, A.M., 1990 (shown as 1988 on p.201): Ronald Campbell Gunn (1808-1881). In Short, P.S. (Ed.): HISTORY OF SYSTEMATIC BOTANY IN AUSTRALASIA. Australian Systematic Botany Society, Melboume.

BuRNs, T. E. \& SREMP, J. R., 1961: VAN DIEMEN'S LAND CORRESPONDENTS. Queen Victoria Museum, Launceston.

DUCKER, S.C., 1988: THE CONTENTED BOTANIST. LETTERS OF W.H. HARVEY ABOUT AUSTRALIA AND THE PACIFIC. Melbourne University Press, Melboume: 413 pp.

DUCKER, S. C. \& PERRY, T. M., 1985: James Fleming: the first gardener on the River Yarra, Victoria. Arch. Nat. Hist: 13: 123-140.

Edwards, P. I., 1981: The Joumal of Peter Good. Bull. Brit. Mus. (Nat. Hist.) Hist. Ser. 9 (complete).

FLINDERS, M., 1814:VOYAGETO TERRA AUSTRALLS.G. and W. Nicol, London: 2 vols with atlas.

Gunv, R. C., 1842: Observations on the Flora of Geelong, Port Phillip. Tasm. J. nat. Sci. Statist. etc. 1: 203207.

HISTORICAL RECORDS OF AUSTRALA, 1922: Series III, Vol. 5.

MABBERLEY, D. J., 1985: JUPITER BOTANICUS, ROBERT BROWN OF THE BRITISH MUSEUM. J. Cramer, Braunschweig.
Mamen, J. H., 1909: Records of Tasmanian Botanists. Pap. Proc. R. Soc.Tasm. 1909: 9-29.

Meston, A. L., 1952: THE VAN DIEMEN'S LAND COMPANY 1825-1842. Museum Committee, Launceston.

NAVY LIST, GREAT BRTAIN, 1809-1860: A LST OF THE FLAG OFFICERS OF HIS MAJESTY"S FLEET. M. \& S. Brooke, London.

Norst, M.J., 1989: FERDINAND BAUER, THE AUSTRALIAN NATURAL HISTORY DRAWINGS. Lothian Publishing Company, Melboume.

PowLING, J. W., 1980: PORT FAIRY, THE FIRST FIFTY YEARS, 1837-87. Heinemann, Melboume.

Rosenman, H. (Ed.\& Transl.), 1987: TWO VOYAGESTOTHE SOUTH SEAS by J.S.C Dumont D'Urville, Vol. 1. Melboume University Press, Melbourne.

Ross, J., 1832: HOBART TOWN ALMANACK. J. James, Hobart Town.

SYME, M. A., 1984: SHIPPING ARRIVALS AND DEPARTURES, VICTORIAN PORTS VOL. 1,17981845. Roebuck Society Publication No. 32, Melboume.

TUCKEY, J.H., 1805: AN ACCOUNT OF A VOYAGE IN THE YEARS 1802-3-4. Longman, Hurst, Rees \& Orme, London.

WIIss, J.H., 1949: Botanical Pioneers in Victoria, 1. Vict. Nat. 66: 85-86.

WIUIs, J.H., 1955: Robert Brown's collectings in Victoria. Muelleria 1: 51-54.

WILLIS, J.H., 1959: Botanical science in Victoria 100 years ago. Proc. R. Soc.Vict. 73: 41-45.

WIIIS, J.H., 1966: Vegetation. In PORT PHILLIP SURVEY 1957-1963. Mem. nat. Mus. Vict. 27: 119-132.

WuIs, J.H. \& SkEwEs, C.I., 1955: Robert Brown's Bass Strait Joumal of April/May 1802. Muelleria 1: 46-50.

(accepted 2 February 1990)

S.C. Ducker

School of Botany, University of Melboume, Parkville, Victoria, Australia 3052. 


\section{APPENDIX \\ Plants and Birds Mentioned in the Text}

PLANTS

Acacia

Aster

Banksia Australis

Banksia

Bursaria

Calystegia sepium

Cassytha

Correa Backhousiana

Correa

Daviesia latifolia

Eucalyptus

Exocarpos Cupressiformis

Fabricia Gaertn.

Lavatera $\mathbf{L}$.

Lotus L.

Lythrum salicaria

Ozothamnus.

Pomaderris

Salicornia

Senecio

Typha

Xanthorrhae
Member of the Asteraceae, Gunn is probably referring to a species of Olearia.

Banksia marginata Cav. or B. integrifolia L.f.

Bursaria spinosa Cav.

Calystegia sepium (L.) R.Br.

Correa backhousiana Hook.

Daviesa latifolia $\mathrm{R} . \mathrm{Br}$.

Exocarpos cupressiformis Labill.

Leptospermum Forst. \& Forst.f. Gunn was probably referring to $L$. laevigatum (J.Gaertn.) F. Muell.

presumably refers to L. plebeia Sims var. tomentosa Hook.f.

presumably is a reference to L. australis Andr.

Lythrum salicaria $\mathrm{L}$.

now a subgenus of Helichrysum Mill.

Sarcocornia A. J. Scott

\section{BIRDS}

The birds mentioned in the text have been tentatively identified as far as possible and checked for localities in Blakers et al. (1985).

Bellbird [Bell Miner]

Ground Parrot (P.[Psitaccus] terrestris)

large white Gull [Pacific Gull]

Mutton Bird [Short-tailed Shearwater]

Pelican [Australian Pelican]

Sand piper

Shag

small white Gull [Silver Gull]

Swan [Black Swan]
Manorina melanophrys (Latham)

Pezoporus wallicus (Kerr)

Larus pacificus L atham

Puffinus tenuirostris (Temminck)

Pelecanus conspicillatus Temminck. probably the Hooded Plover or another Sandpiper. would be classed as a Cormorant today.

Larus novaehollandiae Stephens

Cygnus atratus (Latham) 